\title{
Final Scientific Report
}

\section{Cover Page}

BARD Project Number: IS-4267-09

Date of Submission of the report: May 31, 2013

Project Title: Desiccation tolerance in Salmonella and its implications

\section{Investigators}

Principal Investigator (PI): S. Sela

Co-Principal Investigator (Co-PI): M. McClelland Collaborating Investigators:

\section{$\underline{\text { Institutions }}$}

The Volcani Center (ARO)

University of California, Irvine

Keywords not appearing in the title and in order of importance. Avoid abbreviations.

Anhydrobiosis, dehydration, stress response, bioinformatics, systems biology

Abbreviations commonly used in the report, in alphabetical order:

DT, dehydration tolerance; det, desiccation tolerance gene; LTP, long-term persistence; STm, S. enterica sv. Typhimurium

Budget: IS: $\$ 159,000 \quad$ US: $\$ 160,000 \quad$ Total: $\$ 319,000$

Signature

Principal Investigator
Signature

Authorizing Official, Principal Institution 
Final Scientific Report

Publication Summary (numbers)

\begin{tabular}{|c|c|c|c|c|}
\hline & $\begin{array}{c}\text { Joint } \\
\text { IS/US } \\
\text { authorship }\end{array}$ & $\begin{array}{l}\text { US Authors } \\
\text { only }\end{array}$ & $\begin{array}{c}\text { Israeli } \\
\text { Authors } \\
\text { only }\end{array}$ & Total \\
\hline $\begin{array}{l}\text { Refereed (published, in press, accepted) } \\
\text { BARD support acknowledged }\end{array}$ & 1 & 8 & 2 & 11 \\
\hline Submitted, in review, in preparation & 1 & - & - & 1 \\
\hline Invited review papers & - & - & - & - \\
\hline Book chapters & - & & - & \\
\hline Books & - & & - & \\
\hline Master theses & - & - & 1 & 1 \\
\hline Ph.D. theses & - & - & 1 & 1 \\
\hline Abstracts & - & - & 1 & 1 \\
\hline Not refereed (proceedings, reports, etc.) & 2 & - & - & 2 \\
\hline
\end{tabular}

Postdoctoral Training: List the names and social security/identity numbers of all postdocs who received more than $50 \%$ of their funding by the grant.

Cooperation Summary (numbers)

\begin{tabular}{|l|l|l|l|l|}
\hline & $\begin{array}{c}\text { From US to } \\
\text { Israel }\end{array}$ & $\begin{array}{c}\text { From Israel } \\
\text { to US }\end{array}$ & $\begin{array}{c}\text { Together, } \\
\text { elsewhere }\end{array}$ & Total \\
\hline $\begin{array}{l}\text { Short Visits \& } \\
\text { Meetings }\end{array}$ & - & 1 & - & 1 \\
\hline $\begin{array}{l}\text { Longer Visits } \\
\text { (Sabbaticals) }\end{array}$ & - & - & - & - \\
\hline
\end{tabular}

\section{Description Cooperation:}

Cooperation between the Israeli and the US parties consisted of ongoing discussions through the internet. In addition Dr. Sela has visited Dr. McClelland lab at San-Diego during August 2010 and gave a lecture (acknowledging BARD support) regarding the progress of the project. Dr. Sela met Dr. McClelland and other members of the group. The discussions included analysis of the data obtained at both labs and detailed plans of future experiments. M. McClelland send to S. Sela a collection of Salmonella mutants to be screen for desiccation-sensitive mutants as well as costumed-made slides containing Salmonella DNAmicroarray. These DNA microarrays were used in S. Sela lab to identify Salmonella genes, which are upregulated during dehydration. M. McClelland also assisted in the bioinformatics analysis of the data. These widely useful tools are in active use in this and related project with acknowledgement of BARD. This cooperation has culminated in a joint paper published in the journal of "Applied and Environmental Microbiology" (Gruzdev, M., McClelland, M., Porwollik, S., Ofaim, S., Pinto, R., and Sela-Saldinger, S. (2012). Global transcriptional analysis of dehydrated Salmonella enterica serovar Typhimurium. App. Env. Microbiol. 78:7866-7875.). 


\section{Final Scientific Report}

Patent Summary (numbers)
\begin{tabular}{|l|l|l|l|l|}
\hline & $\begin{array}{c}\text { Israeli } \\
\text { inventor } \\
\text { only }\end{array}$ & $\begin{array}{l}\text { US inventor } \\
\text { only }\end{array}$ & $\begin{array}{c}\text { Joint } \\
\text { IS/US } \\
\text { inventors }\end{array}$ & Total \\
\hline Submitted & - & - & - & - \\
\hline $\begin{array}{l}\text { Issued } \\
\text { (allowed) }\end{array}$ & - & - & - & - \\
\hline Licensed & - & - & - & - \\
\hline
\end{tabular}

\section{$\underline{\text { Abstract }}$}

Salmonella enterica is a worldwide food-borne pathogen, which regularly causes large outbreaks of food poisoning. Recent outbreaks linked to consumption of contaminated foods with low water-activity, have raised interest in understanding the factors that control fitness of this pathogen to dry environment. Consequently, the general objective of this study was to extend our knowledge on desiccation tolerance and long-term persistence of Salmonella. We discovered that dehydrated STm entered into a viable-but-nonculturable state, and that addition of chloramphenicol reduced bacterial survival. This finding implied that adaptation to desiccation stress requires de-novo protein synthesis. We also discovered that dried STm cells develop cross-tolerance to multiple stresses that the pathogen might encounter in the agriculture/food environment, such as high or low temperatures, salt, and various disinfectants. These findings have important implications for food safety because they demonstrate the limitations of chemical and physical treatments currently utilized by the food industry to completely inactivate Salmonella. In order to identify genes involved in desiccation stress tolerance, we employed transcriptomic analysis of dehydrated and wet cells and direct screening of knock-out mutant and transposon libraries. Transcriptomic analysis revealed that dehydration induced expression of ninety genes and down-regulated seven. Ribosomal structural genes represented the most abundant functional group with a relatively higher transcription during dehydration. Other large classes of induced functional groups included genes involved in amino acid metabolism, energy production, ion transport, transcription, and stress response. Initial genetic analysis of a number of up-regulated genes was carried out). It was found that mutations in $r p o \mathrm{~S}, y a h \mathrm{O}$, ace $\mathrm{A}, n i f \mathrm{U}, r p o \mathrm{E}, d d g, f n r$ and $k d p \mathrm{E}$ significantly compromised desiccation tolerance, supporting their role in desiccation stress response. 


\section{Evaluation of the research achievements}

Salmonella enterica is a worldwide food-borne pathogen, which regularly causes large outbreaks of food poisoning. Recent outbreaks linked to consumption of contaminated foods with low water-activity, have raised interest in understanding the factors that control fitness of this pathogen to dry environment. Consequently, the general objective of this study was to extend our knowledge on desiccation tolerance and long-term persistence of Salmonella.

The specific objectives were as follows: (1) Expand the knowledge on Salmonella anhydrobiosis and characterize environmental factors that might affect desiccation and long term survival in the air-dried state; (2) Examine the effect of desiccation on tolerance to other stressors (cross-tolerance), such as temperature, osmolarity, $\mathrm{pH}, \mathrm{UV}$-irradiation and disinfection agents; (3) Determine the effect of desiccation on virulence in a mouse model of oral infection; (4) Identify candidate genes important for desiccation tolerance and long-term persistence: (5) Functionally characterize desiccation-tolerance genes in various food-related models.

We have met most of the objectives, and a brief summary of the major results is listed here. We performed an initial characterization of environmental factors that affect the tolerance of S. enterica serovar Typhimurium (STm) to desiccation. We discovered that dehydrated STm entered into a viable-but-nonculturable state, and that addition of chloramphenicol reduced bacterial survival. This finding implied that adaptation to desiccation stress requires de-novo protein synthesis (Gruzdev et al., 2012a). We also discovered that dried STm cells develop cross-tolerance to multiple stresses that the pathogen might encounter in the agriculture/food environment, such as high or low temperatures, salt, and various disinfectants (Gruzdev et al., 2011). These findings have important implications for food safety because they demonstrate the limitations of chemical and physical treatments currently utilized by the food industry to completely inactivate Salmonella. In order to identify genes involved in desiccation stress tolerance, we employed two approaches: (a), transcriptomic analysis of dehydrated and wet cells using microarrays; and (b), direct screening of knock-out mutant and transposon libraries. The initial characterization of the insertion positions in the transposon library constructed for this project is now published (Canals et al., BMC Genomics, 2012). The ongoing results of the screens are presented in tables later in the report. Transcriptomic analysis revealed that dehydration induced expression of ninety genes and down-regulated seven. Ribosomal structural genes represented the most abundant functional group with a relatively higher transcription during dehydration. Other large classes of induced functional 


\section{Final Scientific Report}

groups included genes involved in amino acid metabolism, energy production, ion transport, transcription, and stress response. Initial genetic analysis of a number of up-regulated genes was carried out and revealed the involvement of ace A, nif $\mathrm{U}, r p o \mathrm{E}, d d g$, fnr and $k d p \mathrm{E}$ in the Salmonella desiccation stress response (Gruzdev et al., 2012b).

\section{$\underline{\text { Scientific Report }}$}

\section{Effect of environmental factors on desiccation tolerance and long-term persistence}

\section{$\underline{1.1 \text { Effect of osmolarity }}$}

Effect of osmolarity on desiccation tolerance (DT) and long-term persistence (LTP) was examined by comparing STm desiccation in double-distilled water (DDW; hypotonic solution), phosphate buffered saline (PBS-pH 7.2) and increasing concentration of $\mathrm{NaCl}$ (Fig. 1). No significant difference $(\mathrm{P}>0.05)$ in DT or LTP was found between cells desiccated in the presence of PBS and (DDW). Increasing the osmotic strength to $0.125 \mathrm{M} \mathrm{NaCl}$ resulted in higher mortality during desiccation and decreased the LTP at $4^{\circ} \mathrm{C}$. While cells resuspended in DDW and PBS maintained their population during 12 weeks, the cells resuspended in 0.125$1 \mathrm{M} \mathrm{NaCl}$ reached undetectable level after 8-12 weeks of storage.

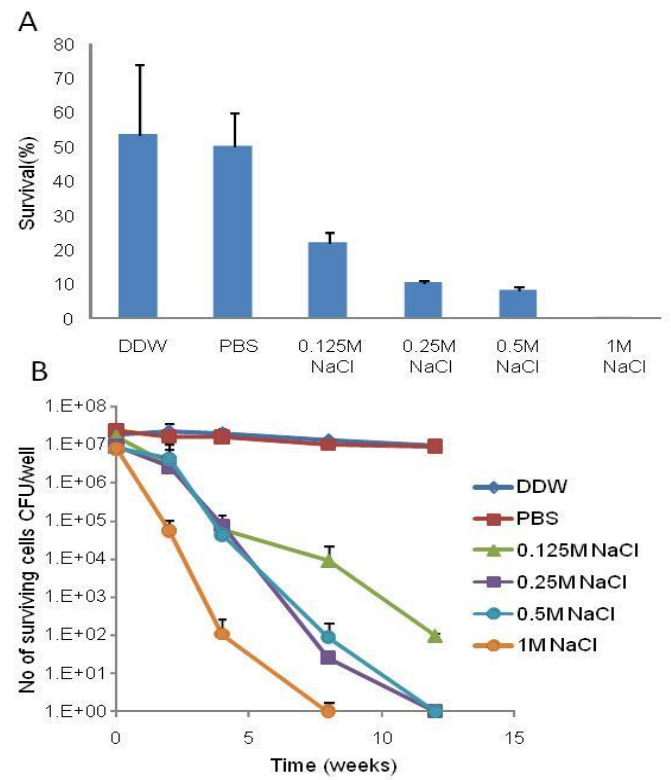

Figure 1. Effect of osmolarity on DT and LTP. Salmonella cells were grown for $20 \mathrm{~h}$ at $37^{\circ} \mathrm{C}$ in $\mathrm{LB}$ plate. Cells were washed three times in DDW, PBS or $\mathrm{NaCl}(0.125,0.25,0.5$ or $1 \mathrm{M})$ and then were resuspended in the indicated solutions to the final concentration of $2 \times 10^{9} \mathrm{CFU} / \mathrm{ml}$. $50 \mu \mathrm{l}$ aliquots were put into wells of 96-wells polystyrene plate. The plate was dried in a Biosafety hood for $22 \mathrm{~h}$ at $25^{\circ} \mathrm{C}$, and then stored for 12 weeks at $4^{\circ} \mathrm{C}$. Viable counts were determined immediately after dehydration and after 2 , 4,8 , and 12 weeks of storage. DT (A) is presented as the average percentage of surviving cells following desiccation $( \pm \mathrm{SD})$ and LTP (B) is presented as the mean viable count $( \pm \mathrm{SD})$ from at least two independent experiments, each performed in triplicate.

\subsection{Effect of $\mathrm{pH}$}

Desiccation of STm was performed under increasing pH values (Fig. 2). Desiccation at acidic conditions resulted in decreased DT (A) and LTP (B), compared to desiccation at high pH values. In fact, cells incubated at $\mathrm{pH} 3$ reached undetectable levels after $22 \mathrm{~h}$ of desiccation. In contrast, cells incubated at $\mathrm{pH} 11$ survived the desiccation with 4-log CFU decrease. Cells 


\section{Final Scientific Report}

desiccated at $\mathrm{pH} 4$ and 5 demonstrated $\sim 6 \log$ reduction within 12 weeks of storage at $4^{\circ} \mathrm{C}$, while cells desiccated at basic environment, except $\mathrm{pH} 11$ maintained their original population.

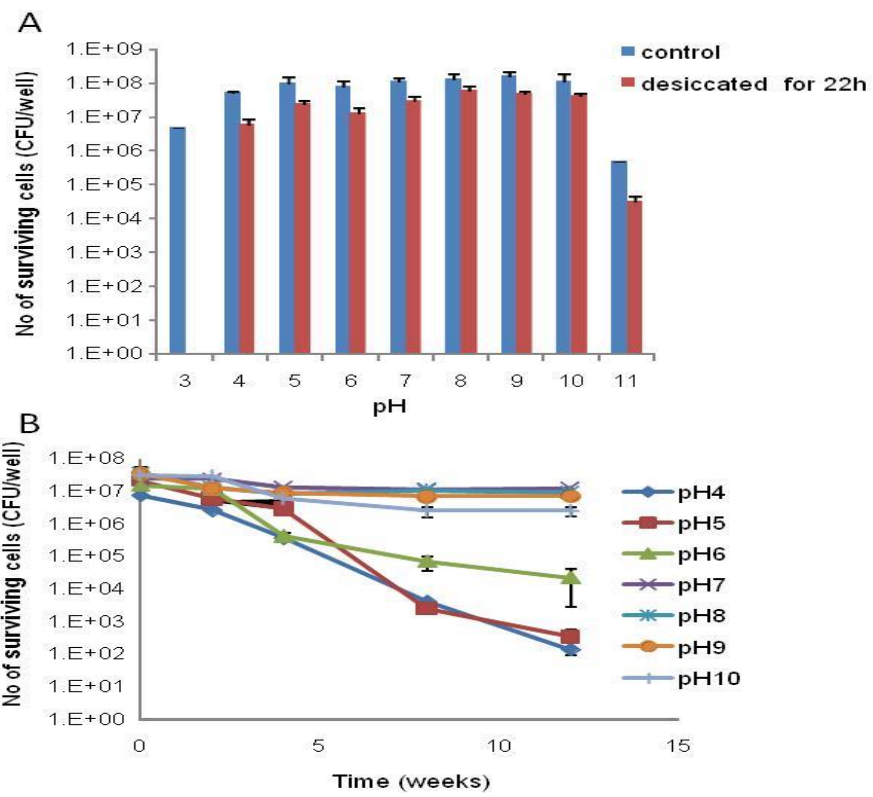

Figure 2. Effect of pH on DT (A) and LTP (B). Bacterial cells were prepared as described in Figure 1. Prior to desiccation cells were resuspended in DDW adjusted to $\mathrm{pH} 3-11$ with $1 \mathrm{M} \mathrm{HCl}$ for acidic solutions and with $1 \mathrm{M} \mathrm{NaOH}$ for basic conditions. Desiccation experiments were performed as described above. Cells incubated for $22 \mathrm{~h}$ in DDW (without desiccation) served as a control. Average viable counts $( \pm \mathrm{SD})$ from three independent experiments are presented.

\subsection{Effect of duration of desiccation process}

Effect of the time of dehydration on DT and LTP was also determined (Fig. 3). Bacterial cells $\left(10^{8} \mathrm{CFU}\right)$ suspended in 15,25 and $50 \mu \mathrm{l}$ were dried until no water was visually apparent $(6.5$, 11 and $22 \mathrm{~h}$, respectively). Shorter desiccation time has reduced both DT (3A) and LTP (3B) scores compared to cells dehydrated in $50 \mu 1$ ( 22 hours to full dehydration).

Figure 3. Effect of dehydration duration on DT and LTP. Bacterial cells were prepared as described in Figure 1. An inoculum of $10^{8} \mathrm{CFU} /$ well in 15,25 and $50 \mu 1$ aliquots was desiccates in 96-well plate for 6.5, 11 and 22 hours respectively to full dehydration. DT is presented as the average percentage of surviving cells $( \pm \mathrm{SD})(\mathrm{A})$, and LTP is presented as the mean viable count $( \pm \mathrm{SD})(\mathrm{B})$ from three independent experiments, each performed in triplicate.

\subsection{Effect of nutrients and compatible solutes}

Effect of exogenous nutrients and compatible

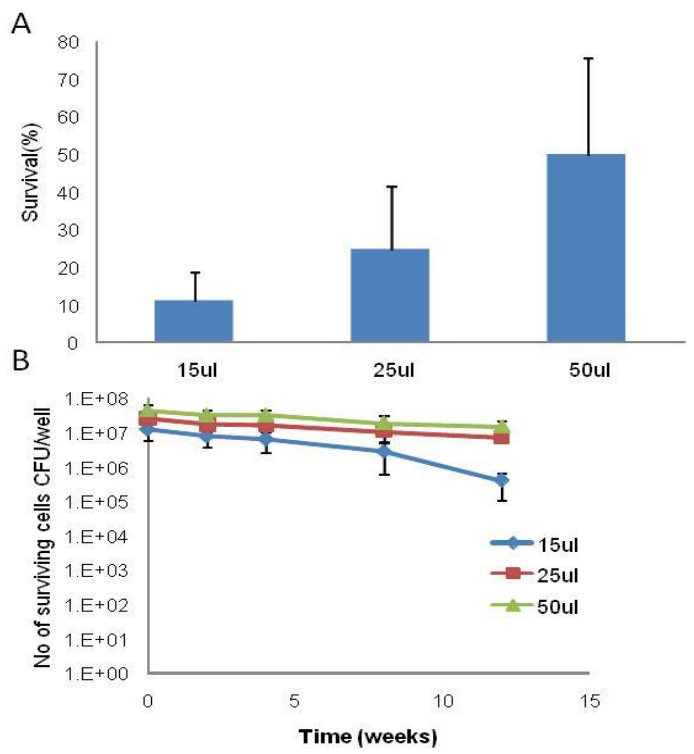
solutes on DT and LTP was tested (Fig. 4) STm cells dried in LB medium and in 100mM trehalose or sucrose, demonstrated significantly higher DT compared to cells desiccated in 


\section{Final Scientific Report}

DDW. In contrast, addition of $100 \mathrm{mM}$ of glycine-betaine to the drying cells, didn't affect DT (4A). Drying in trehalose or sucrose solution, but not glycine-betaine or LB, has increased LTP (4B).

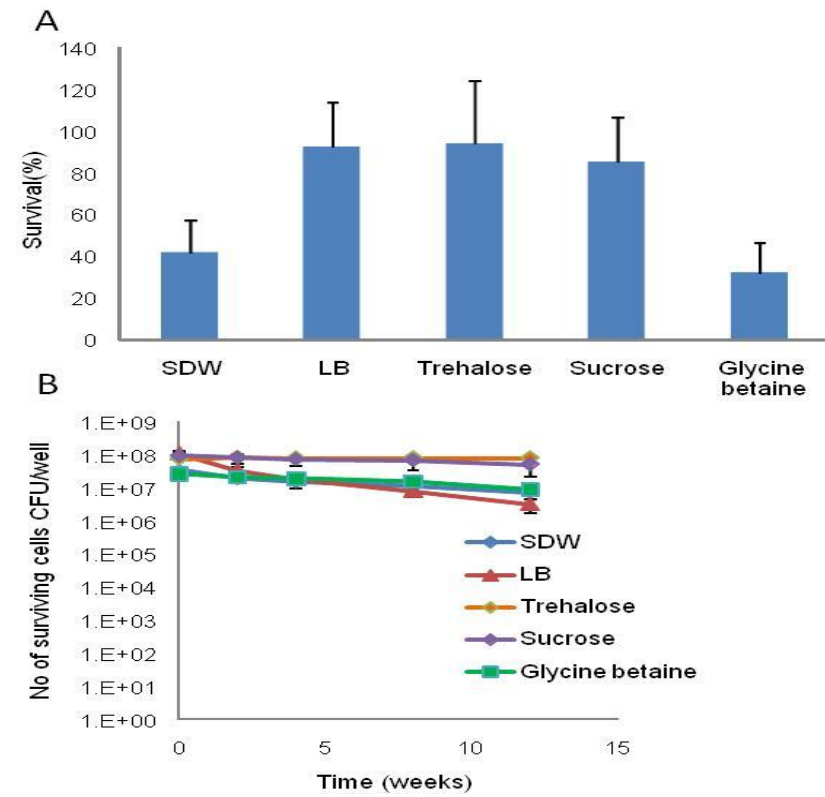

Figure 4. Effect of compatible solutes and nutrients on DT and LTP. Bacterial cells were prepared as described in Figure 1. Prior to desiccation bacteria were resuspended in SDW, LB broth, $100 \mathrm{mM}$ trehalose, sucrose or glycine betaine. Desiccation experiments were performed as described above. DT is presented as the average percentage of surviving cells $( \pm \mathrm{SD})$ $(\mathrm{A})$, and LTP is presented as the mean viable count $( \pm \mathrm{SD})$ (B) from two independent experiments, each performed in triplicate.

\subsection{Effect of growth-phase}

Effect of bacterial growth-phase on DT and LTP was also tested (Fig. 5). Cells derived from logarithmic growth phase $(4 \mathrm{~h})$ were more sensitive to desiccation $(\mathrm{A})$, and exhibited lower DT and LTP (B) compared to cells derived from stationary growth phase $(20 \mathrm{~h})$. No significant difference was found between stationary cells grown in liquid (LB broth) or on solid media (LB agar).

Figure 5. Effect of growth-phase on DT and LTP. Cells derived from different growth phases were collected, washed three times in SDW and brought to a final concentration of 2x109 CFU/ml. Desiccation experiments were performed as described above. DT is presented as the average percentage of surviving cells $( \pm \mathrm{SD})(\mathrm{A})$, and LTP is presented as the mean viable count $( \pm \mathrm{SD})(\mathrm{B})$ from three independent experiments, each performed in triplicate.

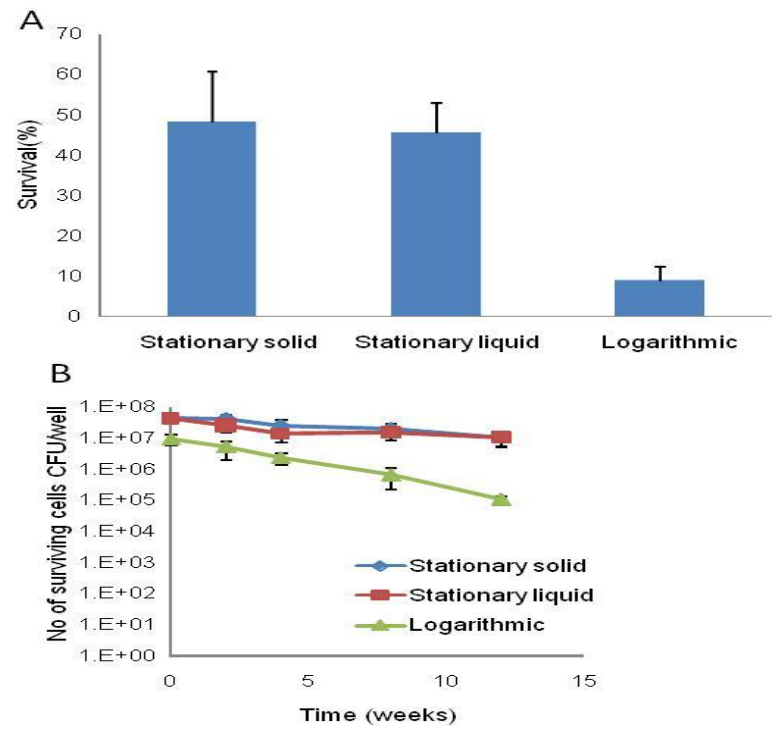




\section{Final Scientific Report}

\section{Examination of the effect of desiccation on tolerance to other stressors}

\subsection{Effect of exposure to $\mathrm{NaCl}$ and bile salts}

Salmonella was exposed to increasing concentrations of $\mathrm{NaCl}$ and bile salts for $2 \mathrm{~h}$ (Fig. 6). Higher DT was observed in desiccated- compared to non-desiccated cells. Furthermore, desiccated cells were able to maintain their original numbers in 1-5\% bile salts and 0.1-0.5 M $\mathrm{NaCl}$, while the number of the control (non-desiccated) cells continuously declined in a dosedependent manner.

Figure 6. Survival of $S$. Typhimurium following exposure to increasing concentrations of $\mathrm{NaCl}(\mathrm{A})$ and bile salts (B). Bacteria were treated and desiccated as described previously. Nondesiccated cells were incubated for $22 \mathrm{~h}$ in SDW at $25^{\circ} \mathrm{C}$. Bacterial cells were exposed to $0.1-1 \mathrm{M}$ of $\mathrm{NaCl}$ and to $1-5 \%$ of bile salts (oxgall) for $2 \mathrm{~h}$.

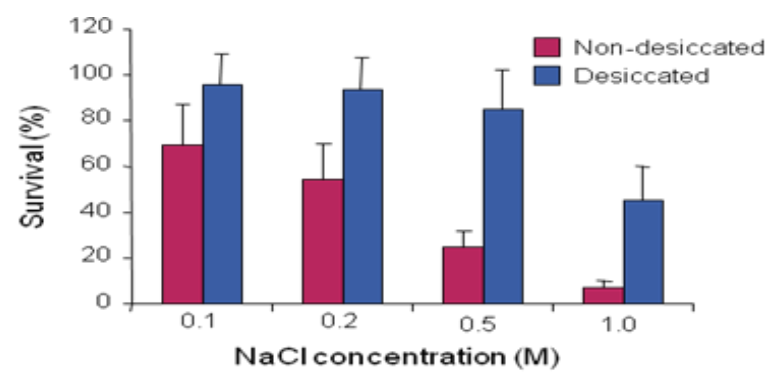
The bars represent the average DT values (+SD) in three independent experiments, each performed in triplicate.

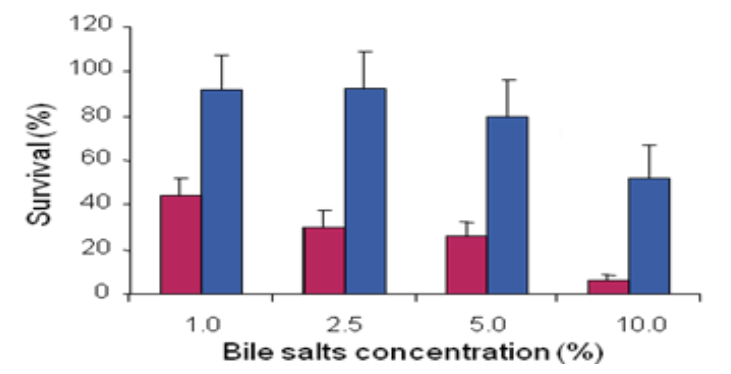

\subsection{Effect of exposure to disinfecting agents}

Salmonella cells were exposed to increasing concentrations of ethanol, hydrogen peroxide, sodium hypochlorite and quaternary ammonium-chloride (DDAC) for the indicated times (Fig. 7).
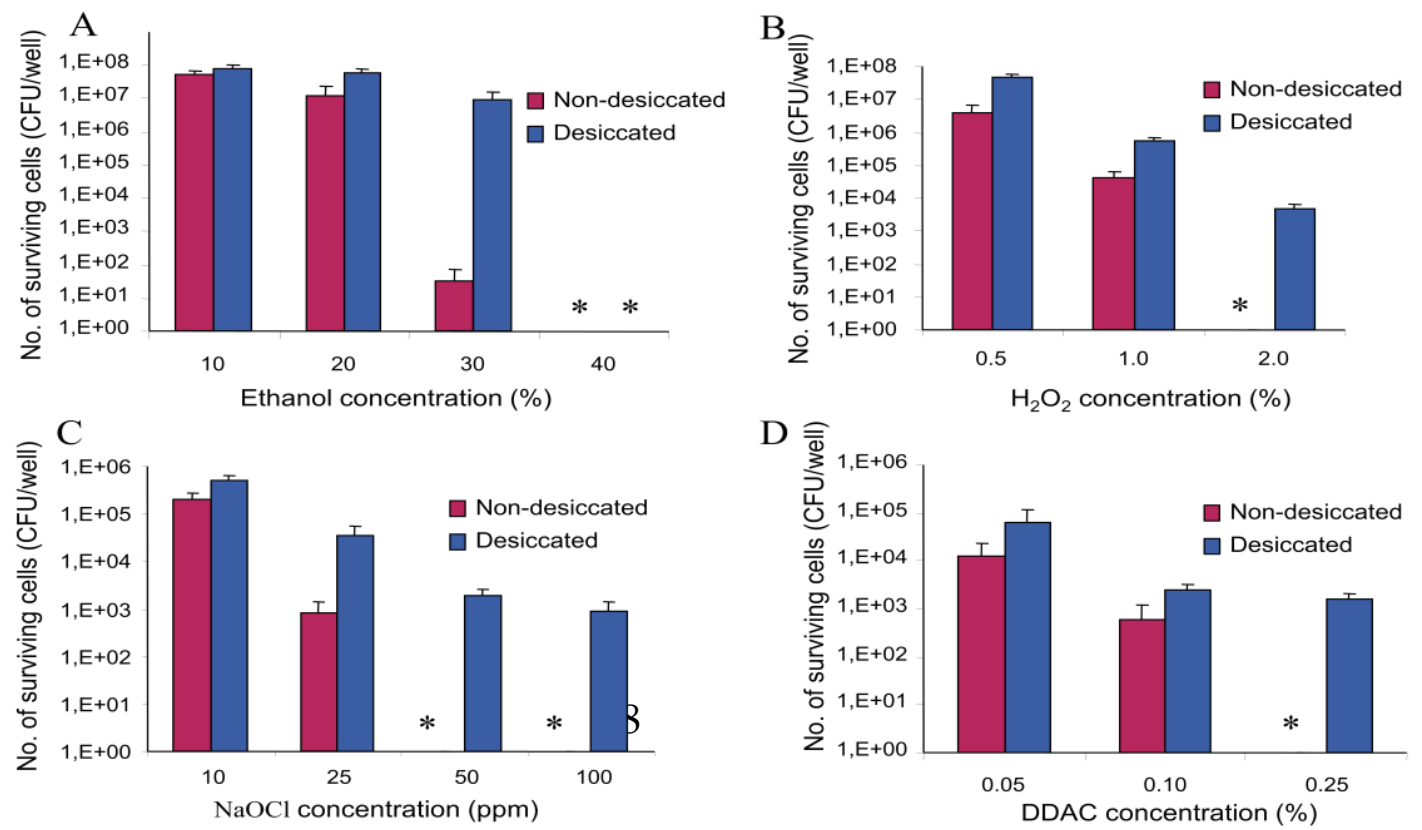


\section{Final Scientific Report}

Figure 7. Effect of disinfecting agents on the survival of desiccated and non-desiccated Salmonella. Desiccated and non-desiccated cells were treated as described for figure 6. Afterwards bacteria were exposed to different concentrations of ethanol for $5 \mathrm{~min}$ (A), hydrogen peroxide for $30 \mathrm{~min}$ (B), sodium hypochlorite for $10 \mathrm{~min}(\mathrm{C})$ and DDAC for $5 \mathrm{~min}(\mathrm{D})$. The average numbers (+SD) of surviving cells from at least two independent experiments are presented. Asterisk denotes Salmonella counts below detection limit $\left(\mathrm{H}_{2} \mathrm{O}_{2}\right.$ and ethanol $<100 \mathrm{CFU}, \mathrm{NaHOCl} 3$ and DDAC $\left.<30 \mathrm{CFU}\right)$.

Desiccated cells demonstrated significantly higher tolerance to all the disinfectants. Moreover, desiccated cells still survived under conditions where non-desiccated cells were undetectable, such as exposure to $2 \%$ hydrogen peroxide for $30 \mathrm{~min}, 50-100 \mathrm{ppm}$ sodium hypochlorite for $5 \mathrm{~min}$, and $0.25 \% \mathrm{DDAC}$ for $5 \mathrm{~min}$. Desiccated cells survived exposure to $30 \%$ ethanol for $5 \mathrm{~min}$ with only $1.0 \mathrm{log}$ reduction, compared to 6.5-log decrease in nondesiccated cells. However, both populations' numbers declined below the detection limit (100 CFU) following exposure to $40 \%$ ethanol for $5 \mathrm{~min}$.

\subsection{Effect of exposure to organic acids}

In contrast to all other stressors, exposure of Salmonella to acetic- or citric-acid at $\mathrm{pH} 3.0$ had an opposite effect on desiccated cells. In both cases, desiccated cells were more susceptible to the acidic conditions compared to non-desiccated cells (Fig. 8).

Figure 8. Effect of organic acids on survival of desiccated and nondesiccated S. Typhimurium. The cells were treated as described for figure 6 and then exposed for 30$120 \mathrm{~min}$ to $50 \mathrm{mM}$ citric acid (A) or $80 \mathrm{mM}$ acetic acid (B), both at $\mathrm{pH}$ 3.0. The average numbers (+SD) of surviving cells from at least two independent experiments are presented.
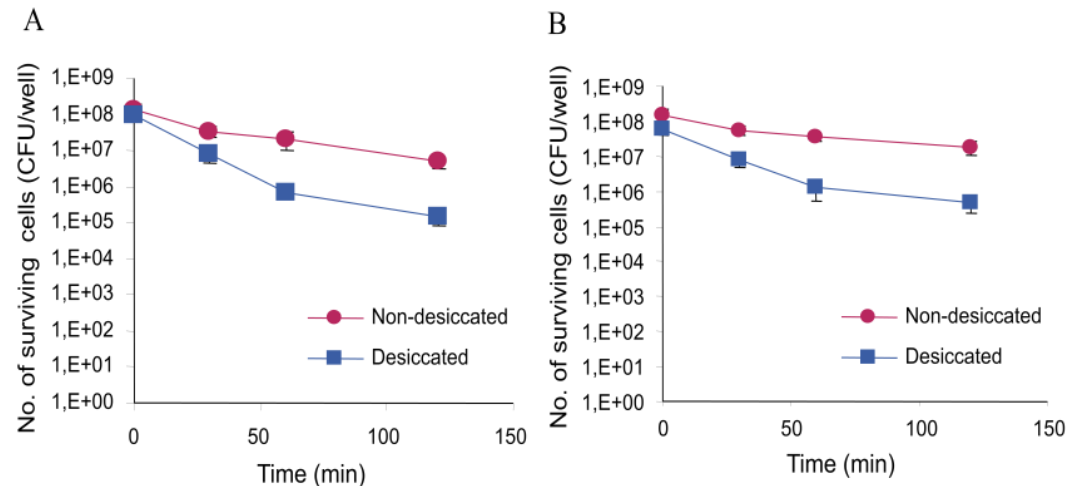

\subsection{Effect of exposure to UV irradiation}

Exposure to UV irradiation $(125 \mu \mathrm{W} / \mathrm{cm} 2)$ for 25 minutes resulted in complete eradication of nondesiccated cells, compared 3-log reduction in desiccated cells (Fig. 9).

Figure 9. Effect of UV irradiation on survival of desiccated and non-desiccated S. Typhimurium. The

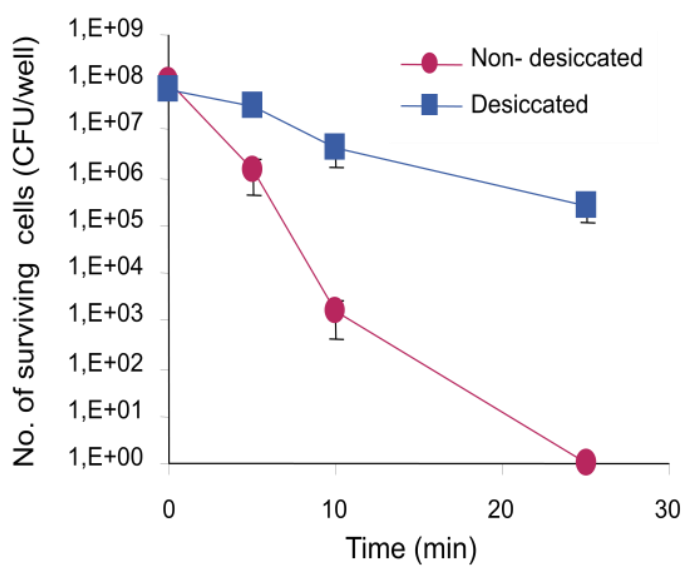




\section{Final Scientific Report}

cells were exposed for 5-25 min to a UV irradiation $(125 \mu \mathrm{W} / \mathrm{cm} 2)$. The average numbers $(+\mathrm{SD})$ of surviving cells from at least two independent experiments are presented.

\subsection{Effect of exposure to dry heat}

Desiccated cells have demonstrated high tolerance to $1 \mathrm{~h}$ exposure to dry heat with apparently no change in the viable count at $60^{\circ} \mathrm{C}$, and 1.5 - and $3.1-\log$ reduction at 80 and $100^{\circ} \mathrm{C}$, respectively. In contrast, non-desiccated cells were highly suceptible, with as much as $3 \log$ reduction at $60{ }^{\circ} \mathrm{C}$, and 8 -log reduction (under detection limit) at 80 and $100{ }^{\circ} \mathrm{C}$. To examine if desiccated bacteria could still maintain heat tolerance after rehydration, desiccated cells were rehydrated with SDW immediately before exposure to heat. No significant difference was found between rehydrated and non-desiccated bacteria (Fig. 10A).

Since exposure to 80 and $100{ }^{\circ} \mathrm{C}$ for $1 \mathrm{~h}$ resulted in complete eradication of nondesiccated Salmonella, we have also investigated the killing kinetics at $100{ }^{\circ} \mathrm{C}$. While, non-desiccated cells were completely inactivated within $10 \mathrm{~min}$, and rehydrated cells were killed after $20 \mathrm{~min}$, the desiccated cells remained viable with only a 3-log CFU reduction at $60 \mathrm{~min}$ (Fig. 10B).

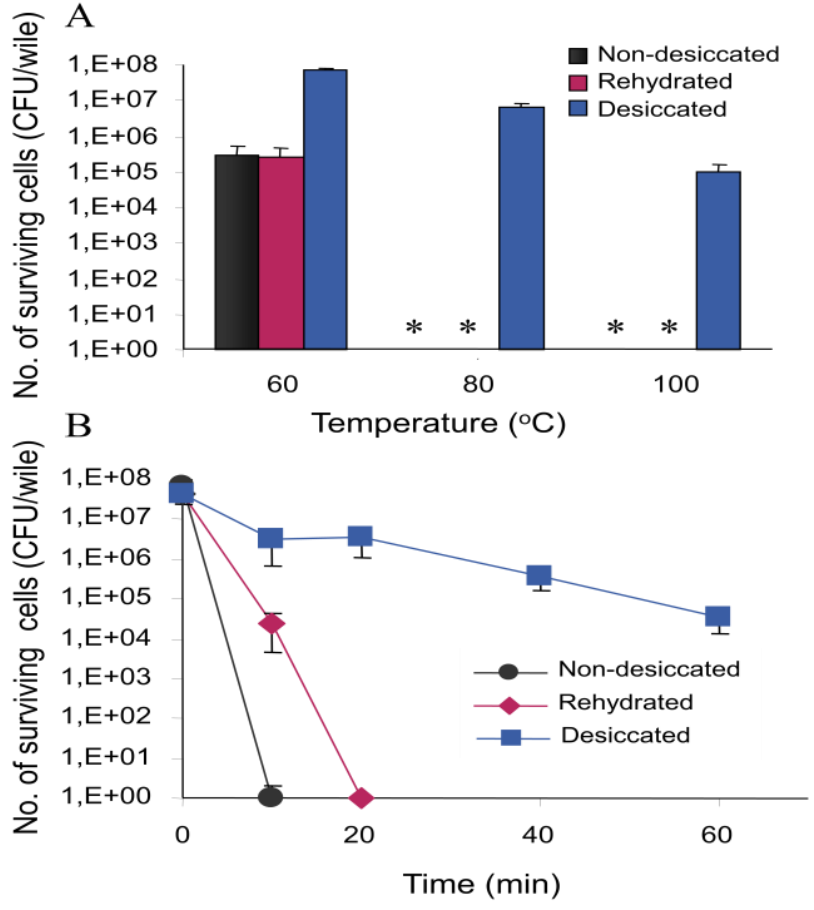

Figure 10. Effect of desiccation on thermal tolerance of Salmonella. Desiccated, nondesiccated and rehydrated cells were exposed to temperatures of 60,80 and $100^{\circ} \mathrm{C}$ for $1 \mathrm{~h}(\mathrm{~A})$, or to $100^{\circ} \mathrm{C}$ for up to $60 \mathrm{~min}$ (B). The average numbers of surviving cells (+SD) from at least two independent experiments are presented. Asterisk denotes Salmonella counts below detection limit $(<10 \mathrm{CFU})$.

\subsection{Effect of desiccation on cross-tolerance in other Salmonella serotypes}

To examine wether the cross-tolerance phenomenon is unique to $\mathrm{S}$. Typhimurium strain SL1344, the response of serotypes Enteritidis, Hadar, Infantis, and Newport to the same stressors was tested (Table 1). Similar to $S$. Typhimurium, desiccation significantly ( $<<0.01$ ) enhanced the tolerance of all four serotypes to $\mathrm{NaCl}(1 \mathrm{M}, 2 \mathrm{~h})$ bile salts $(10 \%, 2 \mathrm{~h})$, ethanol $(30 \%, 5 \mathrm{~min})$, dry heat $\left(100^{\circ} \mathrm{C}, 1 \mathrm{~h}\right)$ and $\mathrm{UV}$ irradiation $\left(125 \mu \mathrm{W} / \mathrm{cm}^{2}, 25 \mathrm{~min}\right)$. Except for 


\section{Final Scientific Report}

serotype Hadar, all desiccated strains survived exposure to sodium hypochlorite (100 ppm, 5 $\mathrm{min})$, hydrogen peroxide $(2 \%, 5 \mathrm{~min})$ and DDAC $(0.25 \%, 5 \mathrm{~min})$ with 4-6 $\log \mathrm{CFU}$ reduction, while non- desiccated cells reached undetectable levels (>7.0 log CFU reduction) under these conditions. Exposure of all strains to citric acid (50 mM, pH 3.0) resulted in significantly $(\mathrm{p}<0.01)$ higher inactivation $(0.6-2.3 \log \mathrm{CFU}$ reduction) in desiccated cells compared to non-desiccated bacteria (0.2-0.6 log reduction), as was previously demonstrated for $S$. Typhimurium.

\section{Identification of candidate genes important for desiccation tolerance and long-term persistence}

\subsection{RIVET}

\subsubsection{Identification of desiccation-induced genes}

STm RIVET library, previously constructed in our lab, was used to screen for candidate genes (promoters) involved in desiccation tolerance. The RIVET library was pooled and $10^{8}$ clones per well were air-dried in triplicates, as described above. Following rehydration and resuspension, bacteria were plated on $\mathrm{LB}+10 \%$ sucrose to identify potential promoters which resulted in $t m p R$ activation and the loss of the resl-cassette containing the neo and $s a c B$ genes, encoding for kanamycin resistance gene and levansucrase (Merrell and Camilli, 2000). Following verification of the loss of Kan resistance, chromosomal regions near the 5' of the tnpR gene were identified as described (Caetano-Anollés et al., 1991) and sequenced. Bioinformatic analysis was used to identify regions of potential promoters located upstream of the tnpR insertion. A list of genes, whose putative promoters were potentially activated during desiccation, is presented in Table $\mathrm{S} 1$.

\subsubsection{Functional analysis of selected genes}

Several regulatory and structural genes identified by RIVET were functionally analyzed. Sitespecific deletion mutations were generated in genes $p f l C$, envZ, $m d o H, b a r A$ and the fate of Salmonella wt and mutant strains was tested using the DT and LTP assays (Fig. 11 A,B). Mutants in genes $y f h \mathrm{~A}$ and $\operatorname{barA}$ were significantly $(\mathrm{p}<0.05)$ hampered in DT with around $10 \%$ survival (compared to the wt). Similarly the two mutants were also defective in LTP, with $2 \log$ CFU reduction in $\triangle$ barA mutant and $>7 \log$ CFU reduction in the $\triangle y f h A$ mutant after 2 weeks of storage at $4^{\circ} \mathrm{C}$. In contrast, the wt strain survived well with less than $1 \log$ CFU reduction. 
Final Scientific Report

Figure 11. Functional characterization of selected mutants in genes identified by RIVET. Mutants and wt were treated and desiccated as described previously. The average percentage of surviving cells $( \pm \mathrm{SD})$ for DT (A) and the mean viable counts $( \pm$ SD) for LTP (B) from three independent experiments are presented. Different letters indicate significant differences $(\mathrm{p}<0.05)$ in survival percentages.

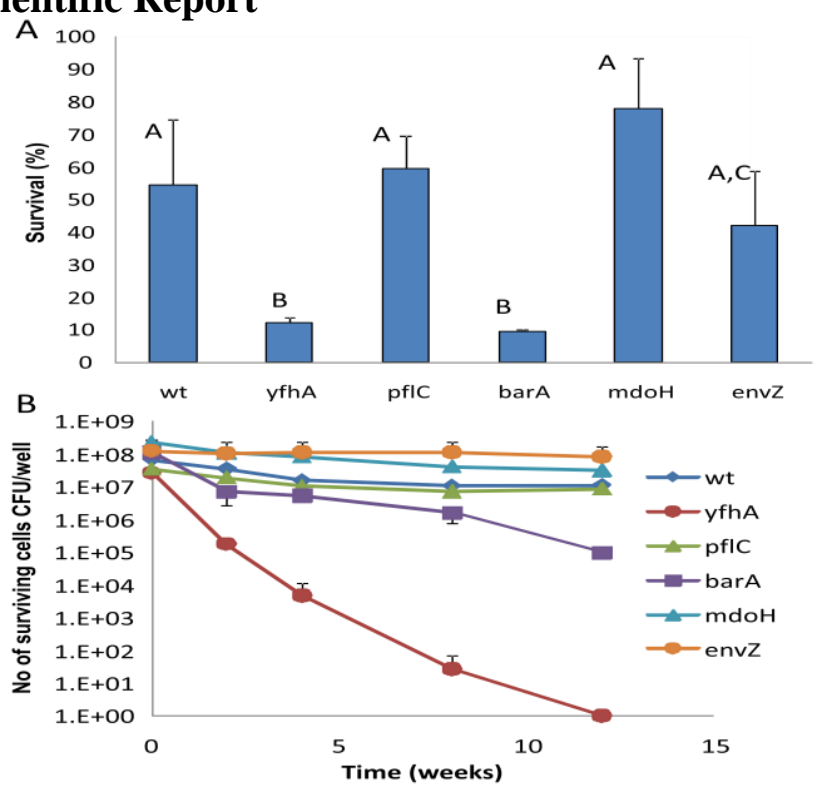

\subsection{Screening of ordered-mutations' library}

A partial ordered STm library (Kan insertions) containing 1036 individual mutations mostly in genes unique to the Salmonella genus, was dried in 20\% sucrose in Dr. McClelland lab and sent to Dr. Sela. The dried mutants were resuscitated by re-suspension in $100 \mu 1 \mathrm{LB}$ broth and incubated at $37 \mathrm{C}$ in an ELISA plate reader. Optical density at $595 \mathrm{~nm}\left(\mathrm{OD}_{595}\right)$ was recorded every $1 \mathrm{~h}$. Mutants which has a longer lag time compared to the WT, but reached the final WT $\mathrm{OD}_{595}$ at $16 \mathrm{~h}$ incubation, were assumed to be putative det mutants. 109 such mutants were identified and 25 of them were individually tested and showed decreased desiccation tolerance compared to the WT strain. The identity of these mutants was verified using specific primers and DNA sequencing. The designated mutations were confirmed in 14 mutants $(60 \%)$ (Table S2). Phage P22 transduction experiments were performed to verify the association between the specific mutations and the DT phenotype. Out of 14 selected transductants that came out by the screening, desiccation-compromised phenotype was confirmed in only two mutants, i.e. rpoS and yahO (Fig. 12A). These mutants were tested for DT and LTP at $4^{\circ} \mathrm{C}$ and the results are illustrated in Fig. 12B. The rpoS deletion mutant was highly impaired in both DT and LTP. This mutant demonstrated very low survival $(\sim 0.1 \%)$ and reached undetectable levels, as early as 4 weeks of cold storage. The second mutant (yahO) was moderately compromised in DT and LTP compared to the WT. 


\section{Final Scientific Report}
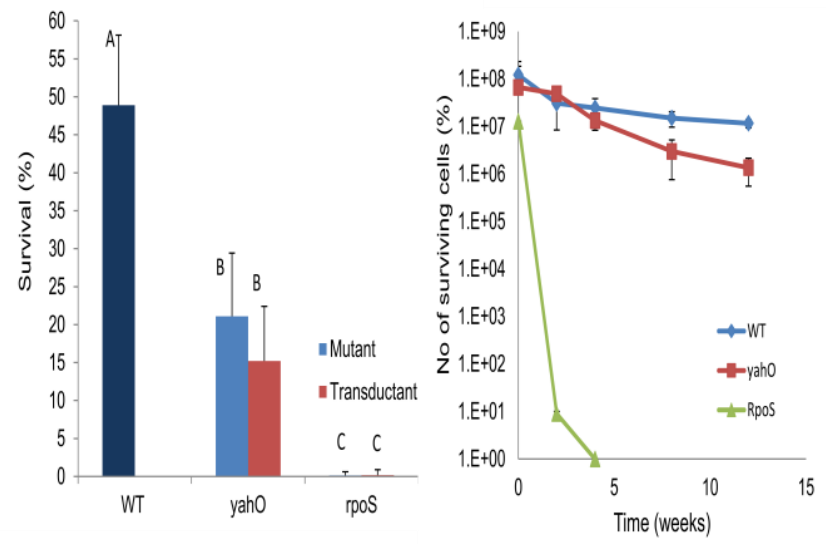

Figure 12. Functional characterization of selected mutants in genes identified by ordered-mutations' library. Mutants, P22 transductants and wt strains were treated and desiccated as described previously. The average percentage of surviving cells $( \pm \mathrm{SD})$ for DT (A) and the mean viable counts $( \pm$ SD) for LTP (B) from three independent experiments are presented. Different letters indicate significant differences $\quad(p<0.05)$ in survival percentages.

\subsection{Identification of candidate det genes by microarray}

Since, the complete ordered mutation library was not ready at the time, McClelland has provided custom-made microarray slides of STm genome in order to facilitate the identification of potential det genes. Total RNA from desiccated and non-desiccated (in SDW) cells incubated for $22 \mathrm{~h}$ at $25^{\circ} \mathrm{C}$ ). RNA was isolated, labeled and hybridized to the Salmonella ORF microarray- chips STv7E at the MicroArray core facility (Faculty of Medicine, Ein Kerem, The Hebrew University, Jerusalem). The microarray study was performed in 4 independent (biological) experiments. The data was analyzed using LIMMA software package. The software provide the statistically significance of differentially expressed genes based on all the arrays on a specific experiment. Results with signal to noise ratio $\geq 1.8\left(\log _{2} \mathrm{FC} \geq 0.85\right)$ with $P<0.05$ were considered significant.

Ninety three up-regulated and 7 down-regulated genes were identified. These genes were further analyzed using Blast2GO (Conesa et al., 2005) tool. General functions of differentially expressed genes ( $\log _{2} \mathrm{FC}$ order) are summarized in Table S3.

\subsubsection{Bioinformatics analysis of positively regulated genes identified by microarray}

The identified genes were analyzed using Blast2GO tool (Conesa et al., 2005) and classified by function, cellular process or cell fracture. (Fig. 13) The largest number (21) of up-regulated genes found to be involved in ribosome structure and biogenesis (Fig 7A) as well as in amino acids transport and metabolism (17). Most of the tested genes has protein (31) and RNA (21) binding activity Fig. 7B). In addition, most of the genes are found to be membrane associated (Fig 13C). 


\section{Final Scientific Report}

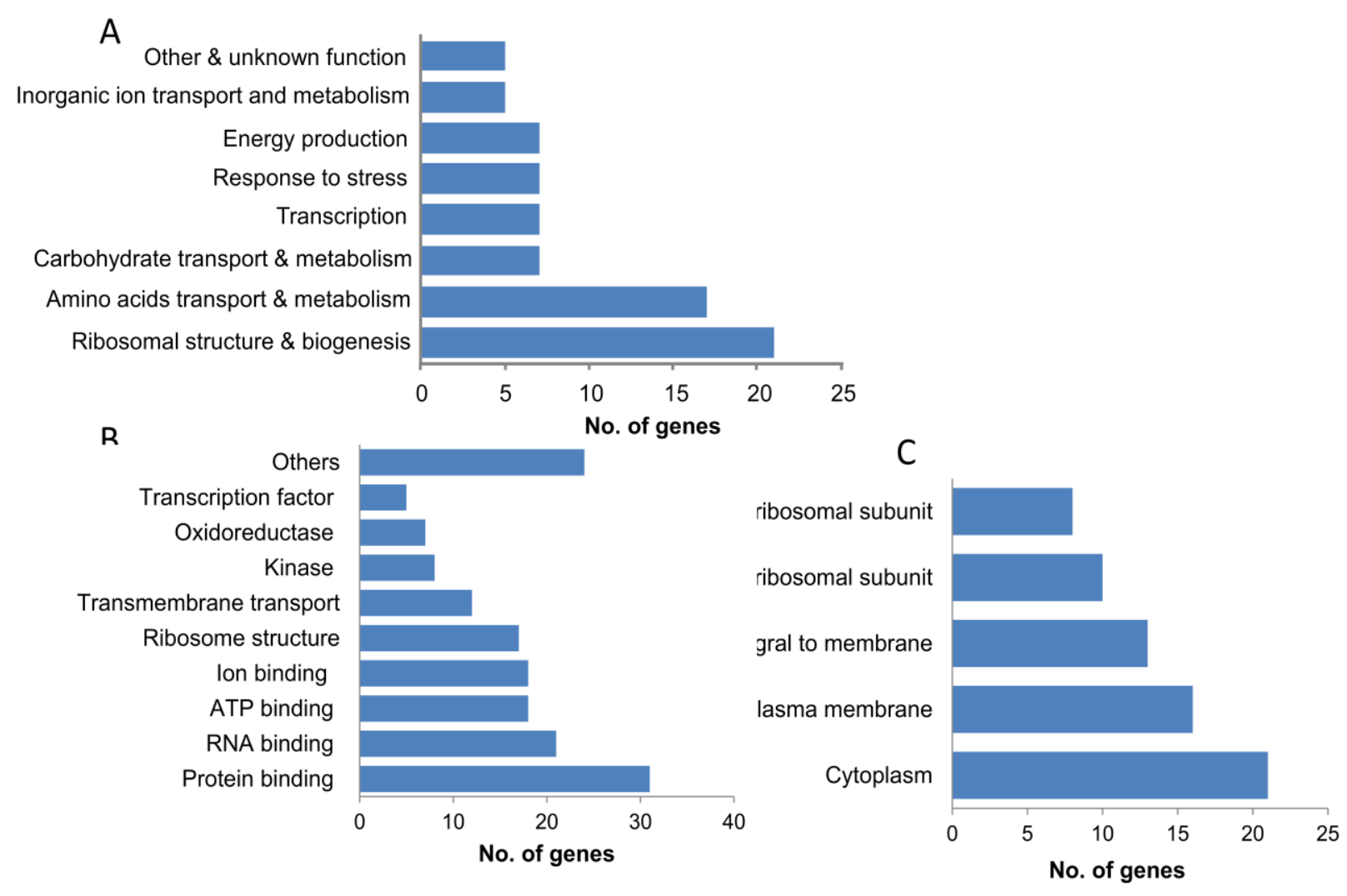

Figure 13. Bioinformatic analysis of up-regulated genes was performed using Blast2GO (Conesa et al., 2005) tool (http://www.blast2go.com/b2ghome). The genes were classified by function (A), cellular process $(\mathrm{B})$ or cellular fracture $(\mathrm{C})$.

\subsubsection{Analysis of up-regulated operones}

Up-regulated genes were analyzed with MicrobesOnline Operon Prediction tool (Price et al., 2005) on (http://www.microbesonline.org/operons/). In general, the up-regulated genes belong to 9 diferent operons involved in pottasium transport, histidine, glutamate, dicarboxylate and glycerophospholipid methabolism, nitrogen fixation, ribosome structure and transcription (Figure S1).

\subsubsection{Functional analysis of selected genes identified by microarray}

From each operon, we selected one gene with the highest fold-change and generated mutations by the $\lambda$ Red Recombinase method (Datsenko and Wanner, 2000). Since $k d p$ operon had the highest fold-change, we decided to generate a mutation also in its regulatory gene, $k d p \mathrm{E}$, although it wasn't detected by the microarray screen. We also generated mutants in the regulatory gene $f n r$, a universal stress protein UspE ( $y d a \mathrm{~A})$, as well as in lipid A biosynthesis palmitoleoyl acyltransferase $(d d g)$. These mutants were tested for DT and LTP (Fig. 14). Mutants in genes ace $\mathrm{A}, n i f \mathrm{U}, r p o \mathrm{E}, d d g, f n r$ and $k d p \mathrm{E}$ demonstrated significantly 


\section{Final Scientific Report}

$(\mathrm{P}<0.05)$ lower DT compared to WT (Fig. 14A). The $k d p E$ mutant had the lowest DT $(1.82 \pm 1.3 \%)$ compared to the WT $(49.9 \pm 9.4 \%)$. This strain had also the lowest persistence at $4^{\circ} \mathrm{C}$ (LTP) reaching undetectable levels after 4 weeks of storage. Four out the five other deletion mutants with lower DT also displayed lower LTP during cold storage with 2-3 log CFU reduction compared to $\sim 1 \log$ reduction in the WT strain (Fig 14B).

Figure 14. Functional characterization of selected mutants in genes identified by microarray. Mutants and wt were treated and desiccated as described previously. The average percentage of surviving cells $( \pm \mathrm{SD})$ for $\mathrm{DT}(\mathrm{A})$ and the mean viable counts $( \pm$ SD) for LTP (B) from three independent experiments are presented. Different letters indicate significant differences $\quad(p<0.05)$ in survival percentages.
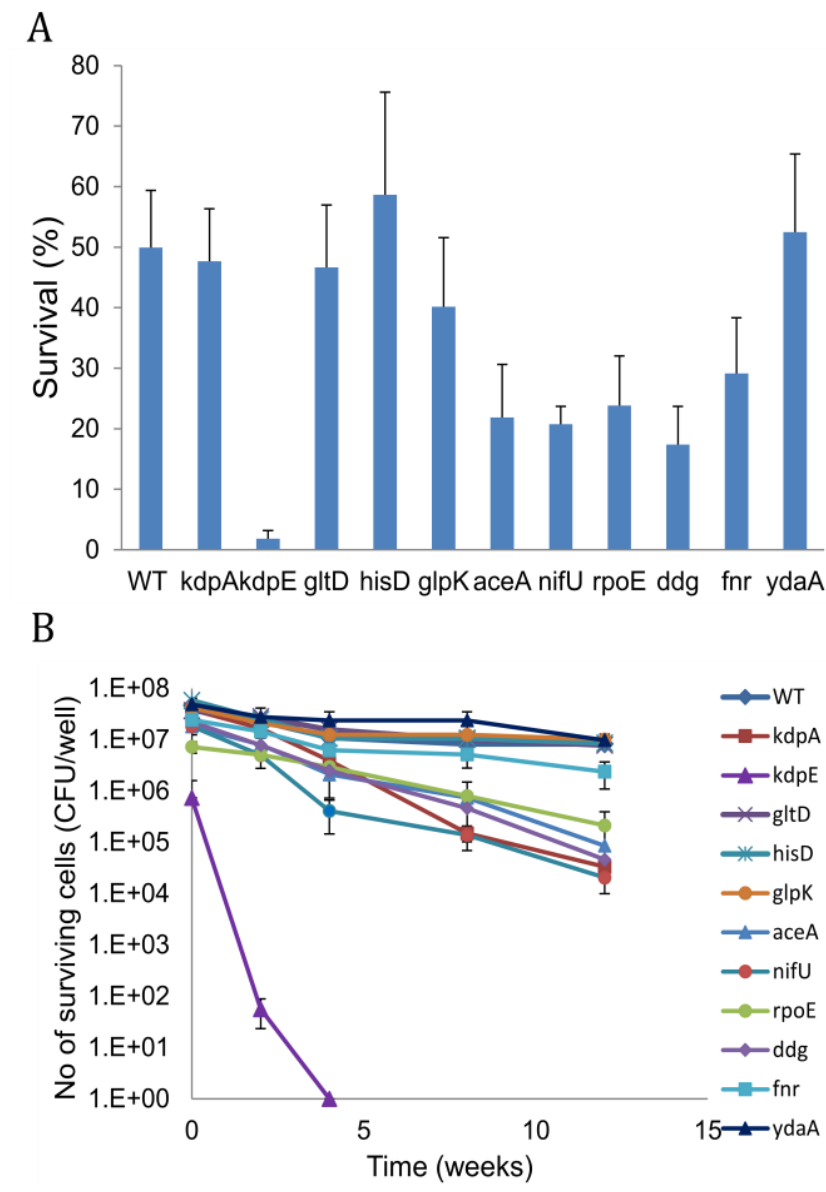

Multiple genes of the histidine and arginine biosynthetic pathways were also induced during dehydration, which perhaps indicates the involvement of the two amino-acids in the adaptation of Salmonella to desiccation. However, neither deletion of the hisGI operon, (histidine biosynthesis), nor deletion of the $\operatorname{argBC}$ operon (synthesis of arginine), affected bacterial survival (Fig.15AB), inferring that histidine and arginine are apparently individually dispensable for survival under dehydration. However, a double mutant $\Delta$ his GI/argBC was compromised both in dehydration tolerance (Fig. 15A) and the long-term persistence (Fig. 15B). Biosynthesis pathways for histidine and arginine are controlled by the $\arg R$ repressor. Although deletion of $\operatorname{argR}$ gene did not affect DT (Fig. 15C) it significantly decreased LTP. The exact role of these two amino acids in desiccation tolerance remain to be studied. 


\section{Final Scientific Renort}
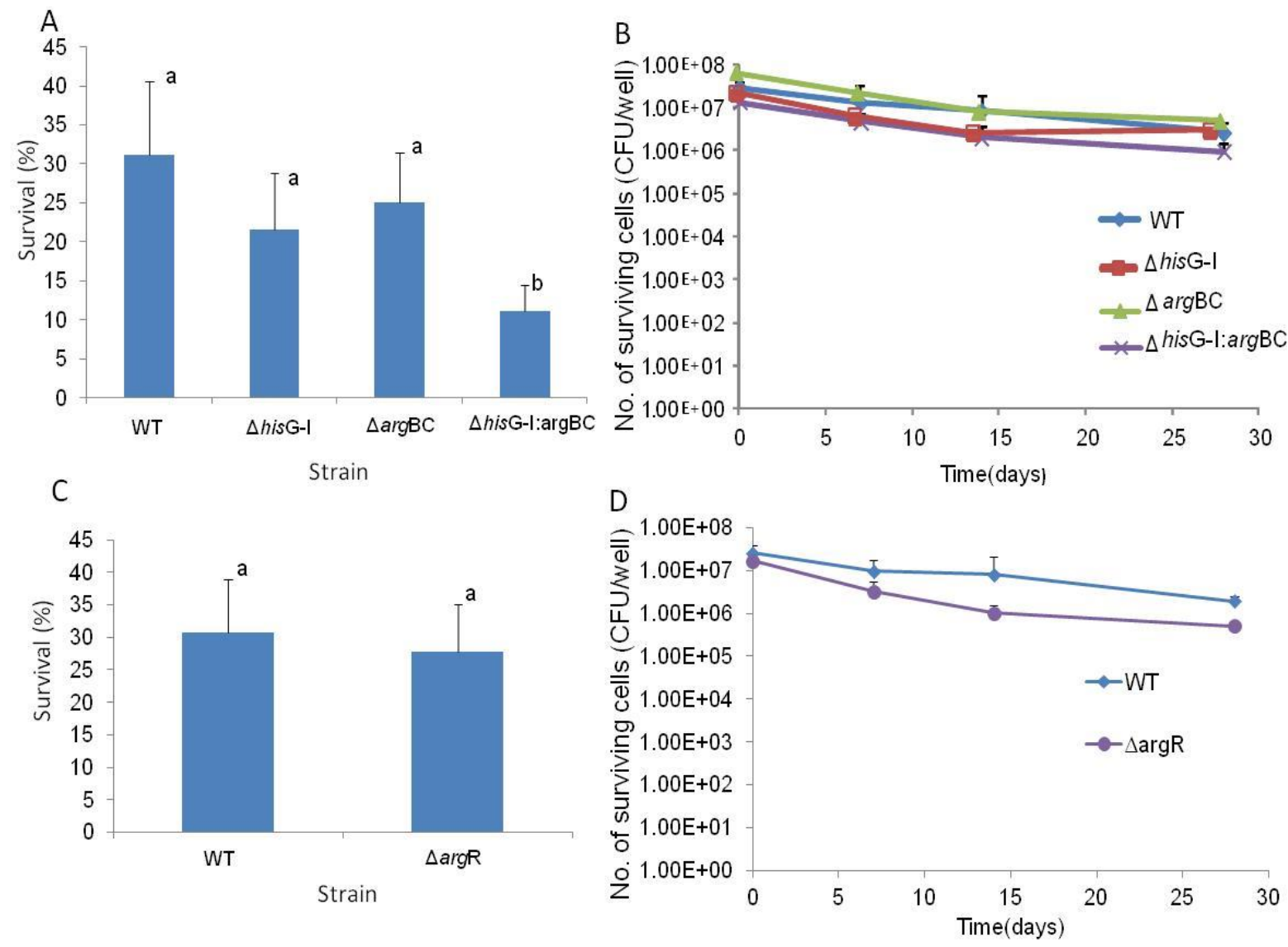

Figure 15. The role of arginine and histidine operons in DT and LTP. A-B: Functional characterization of operons $\operatorname{argBC}$ and hisGI. C-D: functional characterization of ArgR regulator. Mutants and wt were treated and desiccated as described previously. The average percentage of surviving cells $( \pm \mathrm{SD})$ for DT $(\mathrm{A}, \mathrm{C})$ and the mean viable counts $( \pm \mathrm{SD})$ for LTP $(\mathrm{B}, \mathrm{D})$ from three independent experiments are presented. Different letters indicate significant differences $(p<0.05)$ in survival percentages.

Among the dehydration-induced genes, the highest up-regulation was observed in the $k d p \mathrm{ABC}$ genes. This operon encodes a high affinity $\mathrm{K}^{+}$-uptake system in many bacteria. We demonstrated that mutation in operon synthesis activator KdpE, results in extremely impaired DT and LTP phenotype. However, deletion of $k d p \mathrm{ABC}$ operon encoding to proteins responsible to potassium transporting channel structure and assembly, didn't affect survival phenotype (Fig. 16A,B) indicating that involvement of $\mathrm{KdpE}$ in desiccation stress response may occur via activation of factors other than potassium uptake system,

\section{Study the effect of desiccation on Salmonella virulence in mice}




\section{Final Scientific Report}

We first focused on the evaluation of the optimal feeding methodology for the mice experiments with dried feed. Following literature searchs and our own findings regarding cross-tolerance to other stress, we decided that the dried Salmonella cells would be resuspended in sterile double-distilled water and immediately introduce into the mouse by gavage feeding.

Next, we determined the infection efficiency of orally infected mice. The efficiencly varied over three orders of magnitude. This fact precluded the inidvidual measurement of dry versus wet bacteria because reliable results would require a very large number of mice. Thus, we instead compared a mxture of wet versus dry bacteria, together. We prepared Salmonella in 96 well plates by drying in the mediun and condititions described earlier. We prepared plates for three available antibiotic resistances; kanamycin, chloramphenicol, streptomycin, and tetracycline resistance. Each plate was resuspended with freshly grown washed pellet from actively growing bacteria in every pairwise combination and assessed for ratio in vitro. This experimental design ensured that any variation due to differential fitness of strains was controlled.

Next, we performed experiments by gavage in mice and recovered bacteria in the gut and spleen. In control mouse experiment, the standard deviation of counts greatly exceeded the average ratio of antibiotic resistance markers, indicating that the test needed an improvement in power.

We thus designed an alternative strategy, which is ongoing. We inserted different 18 base bar codes into a neutral location in the genome, generating hundreds of clones each with a different barcode. We plan to use these mutants in different mixtures, each treated in a different manners to monitor population complexity and thus infection efficiency. Thus, for example, we could split half of the barcode clones into a dessication class and half into a wet growth class, mix them and then monitor the hundreds of barcodes, simultaneously. This method, by avoiding the use of only two markers per mouse, will be highly tolerant of the vast differences (bottlenecks) we have observed in oral infection. It will also allow us to reduce the dose below the very high, perhaps non-physiological dose, currently used for oral infection. In addition, the strategy holds out the prospect that we could combine a large number of different stress treatments into a single side-by-side measure in the same mouse, relying on a different set of barcodes for each pre-stress. 


\section{Final Scientific Report}

\section{Additional resources developed over the course of the project.}

During the course of the project an additional over 4000 single gene deletion mutants in Typhimurium were made, representing Kanamycin and/or chloramphenicol resistance markers in essentially all genes that can sustain a mutation when growing in Luria Broth. The preliminary quality control analysis of these genes has led to a number of papers. We also have constructed additional transposon libraries in some of the serovars mentioned earlier, in which comparative stress responses may be critical to understanding relative risk. These include Enteritidis and Newport. In related studies, inspired by the need to understand diversity in stress response in the BARD project, we have sequenced additional strains of Enteritidis, Hadar, Infantis, and Newport. Sequence variation between strains may eventually be correlated with stress phenotypes. Finally, the approaches and bioinformatics generated in this project were used in a number of other publications and, accordingly, support from BARD is acknowledged.

\section{$\underline{\text { References }}$}

Conesa A, Götz S., García-Gómez, J.M., Terol, J., Talón, M., and Robles, M. 2005. Blast2GO: a universal tool for annotation, visualization and analysis in functional genomics research. Bioinf. 21:3674-3676.

Datsenko, K. A., and Wanner, B. L. 2000. One-step inactivation of chromosomal genes in Escherichia coli K-12 using PCR products. Proc. Natl. Acad. Sci. U. S. A. 97: 6640-6645.

Price, M.N., Huang, K.H., Alm, E.J., and Arkin, A.P. 2005. A novel method for accurate operon predictions in all sequenced prokaryotes. Nuc. Acid.Res.33:880-892. 


\section{Final Scientific Report}

\section{List of Publications that came out of this study}

Gruzdev, N., Pinto, R., and Sela, S. 2011. Effect of desiccation on tolerance to multiple stresses in Salmonella Typhimurium. Appl. Environ. Microbiol. 77:1667-1673.

Gruzdev, N., Herzberg, S., Pinto, R., and Sela, S. 2012. Persistence of Salmonella enterica during dehydration and subsequent cold storage. Food Microbiol. 32: 415-422.

Gruzdev, M., McClelland, M., Porwollik, S., Ofaim, S., Pinto, R., and Sela-Saldinger, S. 2012. Global transcriptional analysis of dehydrated Salmonella enterica serovar Typhimurium. App. Env. Microbiol. 78:7866-7875.

Canals R, Xia XQ, Fronick C, Clifton SW, Ahmer BM, Andrews-Polymenis HL, Porwollik S, McClelland M. 2012. High-throughput comparison of gene fitness among related bacteria. BMC Genomics 13:212.

\section{List of other Publications that acknowledged support by tools developed in this study}

Noel JT, Arrach N, Alagely A, McClelland M, Teplitski M. 2010. Specific Responses of Salmonella enterica to Tomato Varieties and Fruit Ripeness Identified by In Vivo Expression Technology PLoS One 5:e12406. 20824208.

Cox CE, McClelland M, Teplitski M. 2013. Consequences of disrupting Salmonella AI-2 signaling on interactions within soft rots. Phytopathology. 103:352-61. PMID: 23324045

Das S, Singh S, McClelland M, Forst S, Gyaneshwar P. 2013. Characterization of an acidinducible sulfatase in Salmonella enterica serovar Typhimurium. Appl Environ Microbiol. 79:2092-5. PMID: 23315743

Hung CC, Garner CD, Slauch JM, Dwyer ZW, Lawhon SD, Frye JG, McClelland M, Ahmer BM, Altier C. 2013. The Intestinal Fatty Acid Propionate Inhibits Salmonella Invasion through the Post-translational Control of HilD. Mol Microbiol. 87:1045-60. PMID: 23289537

Chandra M, Cheng P, Rondeau G, Porwollik S, McClelland M. 2013. A single step multiplex PCR for identification of six diarrheagenic E. coli pathotypes and Salmonella. Int J Medical Micro, S1438-4221(13)00038-6. PMID: 23562277

Suez J, Porwollik S, Dagan A, Marzel A, Schorr YI, Desai P, Agmon V, McClelland M, Rahav G, Gal-Mor O. 2013. Virulence Gene Profiling and Pathogenicity Characterization of Non-Typhoidal Salmonella Accounted for Invasive Disease in Humans. PLoS One 8: e58449. PMID: 23505508

Desai P, Porwollik S, Long F, Cheng P, Wollam A, Clifton S, Weinstock G, McClelland M. 2013. Evolutionary genomics of the Salmonella enterica subspecies. mBio 4: e00579-12 PMID: 23462113 


\section{Final Scientific Report}

\section{Supplements}

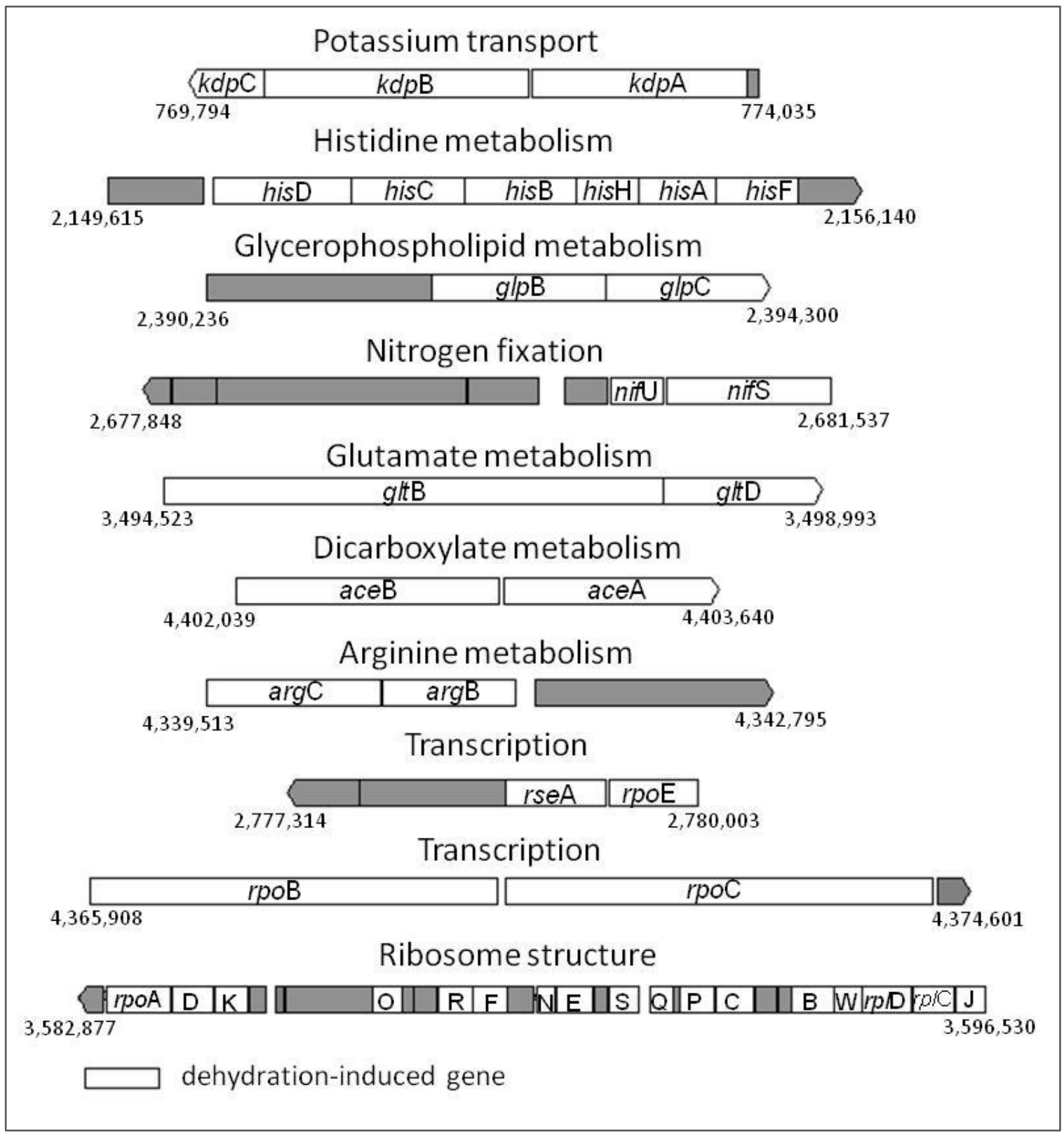

Figure S1. Bioinformatic analysis of up-regulated genes was performed MicrobesOnline Operon Prediction (Price et al., 2005) tool. (http://www.microbesonline.org/operons/) and the genes were divided into operons. The letters in ribosomal structure operon denotes: K-rpsK; O-rplO; R-rplR; N-rpsN; E-rplE; IN-rplN; Q-rpsQ; P-rplP; W-rplW; J-rpsJ. 


\section{Final Scientific Report}

Table S1. A list of putative desiccation-tolerance (det) genes identified by RIVET.

\begin{tabular}{|c|c|}
\hline General function & Gene \\
\hline Signal transduction & $y f h \mathrm{G}, y f h \mathrm{~A}$, envZ, $y o j \mathrm{~N}$, barA, $c s t \mathrm{~A}$ \\
\hline Energy production and conversion & $\begin{array}{l}s u c \mathrm{~A}, a c n \mathrm{~B}, h y b \mathrm{C}, d s b \mathrm{D}, c y d \mathrm{~B}, a s t \mathrm{D}, a d h \mathrm{E}, n u o \mathrm{G}, \\
m a e \mathrm{~B}, y f i \mathrm{Q}, \text { glpK }\end{array}$ \\
\hline Carbohydrate transport and metabolism & $g l g \mathrm{~B}, p t s \mathrm{~A}, m a l \mathrm{G}, m a l \mathrm{~K}$ \\
\hline Amino acids transport and metabolism & 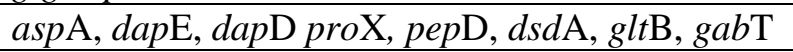 \\
\hline Lipid transport and metabolism & isp $\mathrm{F}$, isp $\mathrm{D}, y f c \mathrm{X}$, tes $\mathrm{A}$ \\
\hline Co-enzymes transport and metabolism & $p d x \mathrm{~J}, y i e \mathrm{E}$ \\
\hline Inorganic ion transport and metabolism & cysI, fieF \\
\hline Nucleotide transport and metabolism & upp \\
\hline Cell wall/ membrane/ envelope biogenesis & $y i g \mathrm{M}, y n f \mathrm{C}, l p x \mathrm{C}, m d o \mathrm{H}, m d o \mathrm{~B}, y e c \mathrm{~B}$ \\
\hline Transcription & $v a c \mathrm{~B}$ \\
\hline $\begin{array}{l}\text { Intracellular trafficking, secretion, and } \\
\text { vesicular transport }\end{array}$ & $s t b \mathrm{C}$, yidC \\
\hline $\begin{array}{l}\text { Posttranslational modification, protein } \\
\text { turnover, chaperones }\end{array}$ & $p f l \mathrm{C}, p t r, y h f \mathrm{~A}, p h n \mathrm{U}$ \\
\hline Replication, recombination and repair. & $y h h \mathrm{~F}, p r i \mathrm{~A}, r e c \mathrm{~A}$ \\
\hline Ribosomal structure & $m i a \mathrm{~B}$ \\
\hline Defense mechanisms & $y b h \mathrm{~F}, a m p \mathrm{E}$ \\
\hline Motility & $y g g \mathrm{R}$ \\
\hline
\end{tabular}

Table S2. List of putative det genes identified by screening of ordered-mutations' library.

\begin{tabular}{|c|c|c|}
\hline $\begin{array}{c}\text { Gene } \\
\text { Symbol }\end{array}$ & Product & General Function \\
\hline STM1665 & putative cytoplasmic protein & Unknown \\
\hline STM0860 & $\begin{array}{c}\text { putative inner membrane protein } \\
(\mathrm{H}+/ \text { gluconate symporter and related } \\
\text { permeases })\end{array}$ & Carbohydrate transport and metabolism \\
\hline STM1328 & putative outer membrane protein & Unknown \\
\hline STM0272 & $\begin{array}{l}\text { putative ATPase with chaperone activity; } \\
\text { homologue of Yersinia clpB }\end{array}$ & $\begin{array}{c}\text { Posttranslational modification,protein } \\
\text { turnover, chaperones }\end{array}$ \\
\hline STM3253 & $\begin{array}{l}\text { putative fructose/tagatose biphosphate } \\
\text { aldolase }\end{array}$ & Carbohydrate transport and metabolism \\
\hline STM1559 & putative glycosyl hydrolase & Carbohydrate transport and metabolism \\
\hline $\mathrm{rfbN}$ & LPS side chain defect: rhamnosyl transferase & Carbohydrate transport and metabolism \\
\hline fliH & $\begin{array}{l}\text { flagellar biosynthesis; possible export of } \\
\text { flagellar proteins }\end{array}$ & Motility \\
\hline rpoS & $\begin{array}{c}\text { sigma S (sigma } 38 \text { ) factor of RNA } \\
\text { polymerase, major sigmafactor during } \\
\text { stationary phase }\end{array}$ & Transcription \\
\hline fljB & $\begin{array}{l}\text { Flagellar synthesis: phase } 2 \text { flagellin } \\
\text { (filament structural protein) }\end{array}$ & Motility \\
\hline yciE & putative cytoplasmic protein & Unknown \\
\hline yfdh & putative glycosyltransferase & Cell wall/ membrane/ envelope biogenesis \\
\hline
\end{tabular}


Final Scientific Report

\begin{tabular}{|c|c|c|}
\hline PhoL & $\begin{array}{c}\text { putative phosphate starvation-inducible } \\
\text { protein }\end{array}$ & Signal transduction mechanisms \\
\hline yahO & putative periplasmic protein & Unknown \\
\hline
\end{tabular}

Table 3S. Genes differentially expressed during desiccation.

\begin{tabular}{|c|c|c|c|}
\hline Gene Symbol & Product & General Function & $\begin{array}{c}\text { log2 } \\
\text { fold- } \\
\text { change }\end{array}$ \\
\hline$k d p B$ & potassium-transporting ATPase subunit B & $\begin{array}{c}\text { Inorganic ion transport and } \\
\text { metabolism }\end{array}$ & 2.33 \\
\hline$k d p A$ & potassium-transporting ATPase subunit A & $\begin{array}{c}\text { Inorganic ion transport and } \\
\text { metabolism }\end{array}$ & 2.22 \\
\hline$k d p C$ & Potassium-transporting ATPase C chain & $\begin{array}{c}\text { Inorganic ion transport and } \\
\text { metabolism }\end{array}$ & 2.17 \\
\hline$d d g$ & lipid A biosynthesis lauroyl acyltransferase & $\begin{array}{c}\text { Lipid transport and } \\
\text { metabolism }\end{array}$ & 1.88 \\
\hline$r p l B$ & 50S ribosomal protein $\mathrm{L} 2$ & $\begin{array}{l}\text { Translation ,ribosomal } \\
\text { structure and biogenesis }\end{array}$ & 1.80 \\
\hline$s l s A$ & putative inner membrane protein & $\begin{array}{c}\text { secondary metabolites } \\
\text { biosynthesis, transport and } \\
\text { catabolism }\end{array}$ & 1.75 \\
\hline aceA & isocitrate lyase & $\begin{array}{l}\text { Energy production and } \\
\text { conversion }\end{array}$ & 1.74 \\
\hline$g l p K$ & glycerol kinase & $\begin{array}{l}\text { Energy production and } \\
\text { conversion } \\
\end{array}$ & 1.68 \\
\hline$r p l E$ & 50S ribosomal protein L5 & $\begin{array}{l}\text { Translation ,ribosomal } \\
\text { structure and biogenesis }\end{array}$ & 1.66 \\
\hline$i s c A$ & iron-sulfur cluster assembly protein & Unknown & 1.65 \\
\hline$y g g N$ & putative periplasmic protein & Unknown & 1.61 \\
\hline $\operatorname{dnaK}$ & molecular chaperone DnaK & $\begin{array}{c}\text { Posttranslational } \\
\text { modification, protein } \\
\text { turnover, chaperones. Stress } \\
\text { response }\end{array}$ & 1.61 \\
\hline $\arg B$ & acetylglutamate kinase & $\begin{array}{c}\text { Amino acids transport and } \\
\text { metabolism }\end{array}$ & 1.60 \\
\hline rplP & 50S ribosomal protein L16 & $\begin{array}{c}\text { Translation ,ribosomal } \\
\text { structure and biogenesis }\end{array}$ & 1.55 \\
\hline aceB & malate synthase & $\begin{array}{c}\text { Energy production and } \\
\text { conversion }\end{array}$ & 1.54 \\
\hline$f t s J$ & 23S rRNA methyltransferase & $\begin{array}{c}\text { Translation ,ribosomal } \\
\text { structure and biogenesis }\end{array}$ & 1.53 \\
\hline$r p l C$ & 50S ribosomal protein L3 & $\begin{array}{c}\text { Translation ,ribosomal } \\
\text { structure and biogenesis }\end{array}$ & 1.51 \\
\hline$h f l B$ & ATP-dependent zinc-metallo protease & $\begin{array}{c}\text { Posttranslational } \\
\text { modification, protein } \\
\text { turnover, chaperones. Stress } \\
\text { response }\end{array}$ & 1.50 \\
\hline$r p l D$ & 50S ribosomal protein $\mathrm{L} 4$ & $\begin{array}{c}\text { Translation ,ribosomal } \\
\text { structure and biogenesis }\end{array}$ & 1.50 \\
\hline $\operatorname{rps} C$ & 30S ribosomal protein $\mathrm{S} 3$ & $\begin{array}{c}\text { Translation ,ribosomal } \\
\text { structure and biogenesis }\end{array}$ & 1.46 \\
\hline$i b p A$ & small heat shock protein & $\begin{array}{c}\text { Posttranslational } \\
\text { modification, protein } \\
\text { turnover, chaperones. Stress } \\
\text { response }\end{array}$ & 1.46 \\
\hline nifU & NifU-like protein & Energy production and & 1.43 \\
\hline
\end{tabular}


Final Scientific Report

\begin{tabular}{|c|c|c|c|}
\hline & & conversion & \\
\hline aceK & $\begin{array}{l}\text { bifunctional isocitrate dehydrogenase } \\
\text { kinase/phosphatase protein }\end{array}$ & $\begin{array}{l}\text { Signal transduction } \\
\text { mechanisms }\end{array}$ & 1.43 \\
\hline$r p l X$ & 50 S ribosomal protein L24 & $\begin{array}{c}\text { Translation ,ribosomal } \\
\text { structure and biogenesis }\end{array}$ & 1.43 \\
\hline rps $J$ & 30S ribosomal protein $\mathrm{S} 10$ & $\begin{array}{l}\text { Translation ,ribosomal } \\
\text { structure and biogenesis }\end{array}$ & 1.43 \\
\hline deaD & cysteine sulfinate desulfinase & $\begin{array}{l}\text { Translation ,ribosomal } \\
\text { structure and biogenesis }\end{array}$ & 1.42 \\
\hline hisF & imidazole glycerol phosphate synthase subunit & $\begin{array}{c}\text { Amino acids transport and } \\
\text { metabolism }\end{array}$ & 1.42 \\
\hline gltD & glutamate synthase small subunit & $\begin{array}{l}\text { Amino acids transport and } \\
\text { metabolism }\end{array}$ & 1.42 \\
\hline hisC & histidinol-phosphate aminotransferase & $\begin{array}{l}\text { Amino acids transport and } \\
\text { metabolism }\end{array}$ & 1.42 \\
\hline rplW & 50S ribosomal protein $\mathrm{L} 23$ & $\begin{array}{l}\text { Translation ,ribosomal } \\
\text { structure and biogenesis }\end{array}$ & 1.39 \\
\hline $\arg G$ & argininosuccinate synthase & $\begin{array}{l}\text { Amino acids transport and } \\
\text { metabolism }\end{array}$ & 1.33 \\
\hline$m g l B$ & galactose transport protein & $\begin{array}{l}\text { Carbohydrate transport and } \\
\text { metabolism }\end{array}$ & 1.32 \\
\hline rpoH & RNA polymerase sigma factor & Transcription & 1.31 \\
\hline$g l p C$ & $\begin{array}{l}\text { sn-glycerol-3-phosphate dehydrogenase K- } \\
\text { small subunit }\end{array}$ & $\begin{array}{l}\text { Energy production and } \\
\text { conversion }\end{array}$ & 1.28 \\
\hline gltB & glutamate synthase large subunit & $\begin{array}{l}\text { Amino acids transport and } \\
\text { metabolism }\end{array}$ & 1.28 \\
\hline$r p s D$ & 30S ribosomal protein $\mathrm{S} 4$ & $\begin{array}{l}\text { Translation ,ribosomal } \\
\text { structure and biogenesis }\end{array}$ & 1.26 \\
\hline hisA & $\begin{array}{c}\text { 1-(5-phosphoribosyl)-5-[(5- } \\
\text { phosphoribosylamino)methylideneamino] } \\
\text { imidazole-4-carboxamide isomerase }\end{array}$ & $\begin{array}{l}\text { Amino acids transport and } \\
\text { metabolism }\end{array}$ & 1.26 \\
\hline rps $H$ & 30S ribosomal protein $\mathrm{S} 8$ & $\begin{array}{l}\text { Translation ,ribosomal } \\
\text { structure and biogenesis }\end{array}$ & 1.25 \\
\hline rpoB & DNA-directed RNA polymerase beta subunit & Transcription & 1.25 \\
\hline rpoC & DNA-directed RNA polymerase beta' subunit & Transcription & 1.23 \\
\hline$i c d A$ & isocitrate dehydrogenase & $\begin{array}{l}\text { Energy production and } \\
\text { conversion }\end{array}$ & 1.23 \\
\hline$y h g I$ & putative thioredoxin-like protein & $\begin{array}{c}\text { Posttranslational } \\
\text { modification, protein } \\
\text { turnover, chaperones. Stress } \\
\text { response }\end{array}$ & 1.23 \\
\hline hisH & $\begin{array}{c}\text { imidazole glycerol phosphate synthase subunit } \\
\text { HisH }\end{array}$ & $\begin{array}{l}\text { Amino acids transport and } \\
\text { metabolism }\end{array}$ & 1.22 \\
\hline$r p l K$ & 50S ribosomal protein $\mathrm{L} 11$ & $\begin{array}{l}\text { Translation ,ribosomal } \\
\text { structure and biogenesis }\end{array}$ & 1.22 \\
\hline $\arg A$ & $\mathrm{~N}$-acetylglutamate synthase & $\begin{array}{l}\text { Amino acids transport and } \\
\text { metabolism }\end{array}$ & 1.20 \\
\hline $\operatorname{rps} K$ & 30S ribosomal protein $\mathrm{S} 11$ & $\begin{array}{c}\text { Translation ,ribosomal } \\
\text { structure and biogenesis }\end{array}$ & 1.19 \\
\hline hisD & histidinol dehydrogenase & $\begin{array}{c}\text { Amino acids transport and } \\
\text { metabolism }\end{array}$ & 1.18 \\
\hline $\arg C$ & $\mathrm{~N}$-acetyl-gamma-glutamyl-phosphate reductase & $\begin{array}{c}\text { Amino acids transport and } \\
\text { metabolism }\end{array}$ & 1.17 \\
\hline$r p s Q$ & 30S ribosomal protein $\mathrm{S} 17$ & $\begin{array}{l}\text { Translation ,ribosomal } \\
\text { structure and biogenesis }\end{array}$ & 1.17 \\
\hline nifS & Cysteine desulfurase & $\begin{array}{l}\text { Amino acids transport and } \\
\text { metabolism }\end{array}$ & 1.16 \\
\hline hisB & $\begin{array}{l}\text { imidazole glycerol-phosphate } \\
\text { dehydratase/histidinol phosphatase }\end{array}$ & $\begin{array}{l}\text { Amino acids transport and } \\
\text { metabolism }\end{array}$ & 1.16 \\
\hline
\end{tabular}


Final Scientific Report

\begin{tabular}{|c|c|c|c|}
\hline rpoE & RNA polymerase sigma-70 factor & Transcription & 1.15 \\
\hline$n l p D$ & lipoprotein & $\begin{array}{l}\text { Cell wall/ membrane/ } \\
\text { envelope biogenesis }\end{array}$ & 1.14 \\
\hline$h s l U$ & ATP-dependent protease & $\begin{array}{c}\text { Posttranslational } \\
\text { modification, protein } \\
\text { turnover, chaperones. Stress } \\
\text { response }\end{array}$ & 1.13 \\
\hline mtlA & mannitol-specific enzyme IIABC component & $\begin{array}{c}\text { Carbohydrate transport and } \\
\text { metabolism }\end{array}$ & 1.13 \\
\hline $\operatorname{prlC}$ & oligopeptidase A & $\begin{array}{l}\text { Amino acids transport and } \\
\text { metabolism }\end{array}$ & 1.13 \\
\hline$g \operatorname{lp} B$ & $\begin{array}{c}\text { anaerobic glycerol-3-phosphate dehydrogenase } \\
\text { subunit B }\end{array}$ & $\begin{array}{l}\text { Amino acids transport and } \\
\text { metabolism }\end{array}$ & 1.12 \\
\hline fumA & fumarase $\mathrm{A}$ & $\begin{array}{l}\text { Energy production and } \\
\text { conversion }\end{array}$ & 1.12 \\
\hline rpoA & DNA-directed RNA polymerase alpha subunit & Transcription & 1.11 \\
\hline$r p s G$ & 30S ribosomal protein $\mathrm{S} 7$ & $\begin{array}{l}\text { Translation ,ribosomal } \\
\text { structure and biogenesis }\end{array}$ & 1.11 \\
\hline $\mathrm{rplO}$ & 50S ribosomal protein L15 & $\begin{array}{l}\text { Translation ,ribosomal } \\
\text { structure and biogenesis }\end{array}$ & 1.10 \\
\hline groEL & chaperonin GroEL & $\begin{array}{c}\text { Posttranslational } \\
\text { modification, protein } \\
\text { turnover, chaperones. Stress } \\
\text { response }\end{array}$ & 1.08 \\
\hline yceD & putative metal-binding protein & $\begin{array}{c}\text { General function prediction } \\
\text { only }\end{array}$ & 1.06 \\
\hline rseA & $\begin{array}{c}\text { Sigma factor RpoE negative regulatory protein } \\
\text { RseA }\end{array}$ & $\begin{array}{c}\text { Signal transduction } \\
\text { mechanisms }\end{array}$ & 1.03 \\
\hline $\operatorname{exbB}$ & energy transduction protein & $\begin{array}{l}\text { Intracellular trafficking } \\
\text { secretion, and vesicular } \\
\text { transport }\end{array}$ & 1.03 \\
\hline ygjU & putative dicarboxylate permease & $\begin{array}{l}\text { Amino acids transport and } \\
\text { metabolism }\end{array}$ & 1.03 \\
\hline rplJ & 50S ribosomal protein L10 & $\begin{array}{c}\text { Translation, ribosomal } \\
\text { structure and biogenesis }\end{array}$ & 1.02 \\
\hline rplA & 50S ribosomal protein $\mathrm{L} 1$ & $\begin{array}{l}\text { Translation ,ribosomal } \\
\text { structure and biogenesis }\end{array}$ & 1.01 \\
\hline pps & phosphoenolpyruvate synthase & $\begin{array}{c}\text { Carbohydrate transport and } \\
\text { metabolism }\end{array}$ & 1.00 \\
\hline $\arg E$ & acetylornithine deacetylase & $\begin{array}{l}\text { Amino acids transport and } \\
\text { metabolism }\end{array}$ & 0.99 \\
\hline$n l p I$ & lipoprotein & $\begin{array}{l}\text { General function prediction } \\
\text { only }\end{array}$ & 0.98 \\
\hline $\operatorname{six} A$ & phosphohistidine phosphatase & $\begin{array}{c}\text { Signal transduction } \\
\text { mechanisms }\end{array}$ & 0.97 \\
\hline phoH & phosphate starvation-inducible protein & $\begin{array}{l}\text { Signal transduction } \\
\text { mechanisms }\end{array}$ & 0.96 \\
\hline$p g k$ & phosphoglycerate kinase & $\begin{array}{c}\text { Carbohydrate transport and } \\
\text { metabolism }\end{array}$ & 0.96 \\
\hline$y c j X$ & putative ATPase & $\begin{array}{l}\text { General function prediction } \\
\text { only }\end{array}$ & 0.95 \\
\hline prpE & putative acetyl-CoA synthetase & $\begin{array}{l}\text { Lipid transport and } \\
\text { metabolism }\end{array}$ & 0.95 \\
\hline fusA & elongation factor EF-2 & $\begin{array}{l}\text { Translation, ribosomal } \\
\text { structure and biogenesis }\end{array}$ & 0.95 \\
\hline pckA & phosphoenolpyruvate carboxykinase & $\begin{array}{l}\text { Signal transduction } \\
\text { mechanisms }\end{array}$ & 0.93 \\
\hline phoL & putative phosphate starvation-inducible protein & $\begin{array}{l}\text { Signal transduction } \\
\text { mechanisms }\end{array}$ & 0.93 \\
\hline
\end{tabular}


Final Scientific Report

\begin{tabular}{|c|c|c|c|}
\hline$y d a A$ & universal stress protein UspE. & $\begin{array}{c}\text { Signal transduction } \\
\text { mechanisms }\end{array}$ & 0.92 \\
\hline $\operatorname{glg} A$ & glycogen synthase & $\begin{array}{c}\text { Carbohydrate transport and } \\
\text { metabolism }\end{array}$ & 0.91 \\
\hline miaA & $\begin{array}{l}\text { tRNA delta(2)-isopentenylpyrophosphate } \\
\text { transferase }\end{array}$ & $\begin{array}{l}\text { Translation ,ribosomal } \\
\text { structure and biogenesis }\end{array}$ & 0.90 \\
\hline $\min E$ & $\begin{array}{l}\text { cell division topological specificity factor } \\
\text { MinE. }\end{array}$ & $\begin{array}{l}\text { Cell cycle control, cell } \\
\text { division, chromosome } \\
\text { partitioning }\end{array}$ & 0.89 \\
\hline $\operatorname{glg} P$ & glycogen phosphorylase & $\begin{array}{c}\text { Carbohydrate transport and } \\
\text { metabolism }\end{array}$ & 0.89 \\
\hline$y b e L$ & hypothetical protein STY0704. & Unknown & 0.89 \\
\hline sufD & cysteine desulfurase modulator & $\begin{array}{c}\text { Posttranslational } \\
\text { modification, protein } \\
\text { turnover, chaperones. Stress } \\
\text { response }\end{array}$ & 0.89 \\
\hline fnr & transcriptional regulator & $\begin{array}{c}\text { Signal transduction } \\
\text { mechanisms }\end{array}$ & 0.88 \\
\hline $\operatorname{prpD}$ & 2-methylcitrate dehydratase & $\begin{array}{l}\text { General function prediction } \\
\text { only }\end{array}$ & 0.87 \\
\hline $\arg D$ & DapATase & $\begin{array}{l}\text { Amino acids transport and } \\
\text { metabolism }\end{array}$ & 0.87 \\
\hline $\arg I$ & ornithine carbamoyltransferase & $\begin{array}{l}\text { Amino acids transport and } \\
\text { metabolism }\end{array}$ & 0.87 \\
\hline greA & transcription elongation factor & Transcription & 0.86 \\
\hline STM1731 & putative catalase & $\begin{array}{c}\text { Inorganic ion transport and } \\
\text { metabolism }\end{array}$ & -0.87 \\
\hline STM_sRNA_tke1 & small RNA & small RNA & -0.9 \\
\hline STM_PSLT068 & putative ParB-like nuclease & virulence & -0.9 \\
\hline $\operatorname{traN}$ & mating pair stabilization protein & virulence & -1.1 \\
\hline parA & plasmid partition protein $\mathrm{A}$ & virulence & -1.18 \\
\hline $\operatorname{trbH}$ & conjugative transfer protein & $\begin{array}{c}\text { General function prediction } \\
\text { only }\end{array}$ & -1.26 \\
\hline cutC & Copper homeostasis protein & $\begin{array}{c}\text { Inorganic ion transport and } \\
\text { metabolism }\end{array}$ & -2.04 \\
\hline
\end{tabular}

